\title{
Inbreeding effects in Solanum lycocarpum A. St.-Hil populations, an endangered species of the Brazilian Cerrado
}

\author{
T.M. Moura ${ }^{1}$, M.V.B.M. Siqueira ${ }^{2}$ and G.C.X. Oliveira ${ }^{3}$ \\ ${ }^{1}$ Programa de Pós-Graduação em Biologia Vegetal, Instituto de Biologia, \\ Universidade Estadual de Campinas, Campinas, SP, Brasil \\ ${ }^{2}$ Agência Paulista de Tecnologia dos Agronegócios, \\ Polo Apta Centro Sul, Piracicaba, SP, Brasil \\ ${ }^{3}$ Departamento de Genética, Escola Superior de Agricultura "Luiz de Queiroz", \\ Universidade de São Paulo, Piracicaba, SP, Brasil \\ Corresponding author: T.M. Moura \\ E-mail: tmariamoura@gmail.com
}

Genet. Mol. Res. 12 (4): 6006-6010 (2013)

Received January 25, 2013

Accepted September 15, 2013

Published November 26, 2013

DOI http://dx.doi.org/10.4238/2013.November.26.10

\begin{abstract}
The inbreeding effective population size is an estimate of inbreeding and genetic drift in populations. It is an important tool for conservation genetics because it represents the number of individuals that are effectively contributing alleles to the subsequent generations. Several studies have been published in the last decades on the genetic structure of natural plant populations of the Cerrado, the Central-Brazilian savannahs, but most of them do not present effective size estimates. The objective of this study was to show such estimates for Solanum lycocarpum, a Cerrado species that is in danger of genetic erosion. We utilized microsatellites, isozymes, and 2 natural populations for each marker to estimate the population inbreeding effective size of a group of populations $\left(\hat{N_{\epsilon(v)}}\right)$ and the minimum number of populations that should be conserved $\left(S_{(r e f)}\right)$ in order to retain an effective number of 500 . For the 2 markers that were utilized, only approximately $12 \%$
\end{abstract}


of the individuals are effective in the populations. The value obtained for $S_{(\text {ref })}^{\hat{n}}$ was approximately 80 .

Key words: Effective size; Conservation; Genetic structure; Lobeira; Population genetics

\section{INTRODUCTION}

Population effective size is an estimate of genetic representativeness and a critical parameter in species conservation because it predicts the number of individuals that effectively contribute with alleles to the next generation (Vencovsky and Crossa, 2003; Crossa and Vencovsky, 2011). The effective size is the size of an ideal population that would have accumulated the same loss of heterozygosity due to genetic drift as that of the actual population, and it is influenced by the reproductive system and the crossing rates of the populations (Crossa and Vencovsky, 2011).

On the basis of mathematical modeling, Vencovsky and Crossa $(1999,2003)$ proposed that, for long-term genetic conservation, the ideal effective size that is retained in a population should be at least 500, and they showed how to estimate the minimal number of populations that should be conserved to retain such effective size. Nevertheless, few studies on population genetic structure for conservation purposes present that estimate. Although both the current ecosystem devastation and the danger of genetic erosion in plants are frequently denounced, little has been done to provide practical information for conservation, such as the minimal number of populations to be protected.

Solanum lycocarpum A. St.-Hil is a typical species of Cerrado vegetation and has been considered as a model to study the conservation genetics of plant species (Martins, 2005). Largely distributed across Cerrado's areas (Stehmann et al., 2013), this species presents flowers and fruits throughout the year (Moura et al., 2010). It is a cross-pollinated species, and the pollinator and dispersing agents can carry the genes over long distances (Oliveira-Filho and Oliveira, 1988; Courternay, 1994). In addition, the population genetic structure of this species is relatively well-studied (Martins et al., 2006, 2011; Moura et al., 2009, 2011a,b, 2012), where it was reported that this species is in danger of genetic erosion (Moura et al., 2011a, 2012). However, the estimate of the minimal number of populations for conservation is still lacking. Therefore, the objective of this study is to provide both a genetic effective population size estimate and an estimate of the minimal number of populations for conservation purposes, which can be used as guidelines to establish protection areas.

\section{MATERIAL AND METHODS}

The estimation of the genetic population parameters was done with 2 kinds of molecular marker. Two natural populations with 60 individuals each were genotyped with nuclear microsatellite loci (SSR), and 2 populations (1 with 45 individuals and the other with 60 individuals) were genotyped with isozyme loci. For each marker, a disturbed area without native vegetation (cattle's pasture) and a protected area where the native vegetation is maintained and with less anthropogenic disturbance were analyzed. A description of the populations, the sampling method, the markers' characterization, and the genetic 
structure is given in Moura et al. (2009, 2011a,b).

The inbreeding effective population size $\left(\hat{N_{\epsilon(v)}}\right)$ was estimated according to Vencovsky and Crossa (1999). Because it is not possible to calculate the total number of natural populations, an estimate was obtained with Equation 1, where $\mathrm{S}$ is the number of populations studied and $F_{\mathrm{ST}}$ is an index of the inbreeding that is produced in the consolidated group of populations by its subdivision into separate populations.

$$
N_{e(v)} \stackrel{\sim}{=\frac{S}{2 F_{s t}}}
$$

(Equation 1)

The number of populations $\left(S_{(\text {reff }}\right)$ that should be conserved to retain an effective size of $500\left(N_{e(r e f)}\right)$ was estimated with Equation 2 according to Vencovsky and Crossa $(1999,2003)$, in which $\theta_{\mathrm{p}}$ is the genetic divergence between populations.

$$
N_{e(r e f)}=\frac{S_{(r e f)}}{2 x \theta_{p}}
$$

(Equation 2)

\section{RESULTS}

The effective size of the consolidated group of populations $\left[\hat{\hat{N}_{\epsilon(v)}}\right]$ was similar for both markers that were used (12.5 and 12.3). The minimal number of populations to be conserved in order to retain an effective size of 500 was also similar (80 and 81) for SSR and isozymes markers (Table 1).

Table 1. Population estimates for in situ conservation of Solanum lycocarpum.
\begin{tabular}{lcccc}
\hline Marker & $\mathrm{N}$ & $\hat{\theta_{p}}$ & $\hat{N_{\ell(v)}}$ & $S_{(\text {ef })}^{\wedge}$ \\
\hline SSR & 120 & $0.080^{*}$ & 12.5 & 80 \\
Isozymes & 101 & $0.081^{* *}$ & 12.3 & 81 \\
\hline
\end{tabular}

$\widehat{\mathrm{N}}=$ number of individuals sampled; $\hat{\theta_{p}}=$ estimate of genetic divergence among populations; $\hat{N_{\theta(v)}}=$ effective size for the group of populations; $\hat{S}_{(\mathrm{ref})}=$ minimal number of populations to be conserved to keep an effective size of 500.*Moura et al., 2009, 2011a;**Moura et al., 2011b.

\section{DISCUSSION}

The genetic representativeness for the group of populations $\left[\hat{N_{\epsilon(v)}}\right]$ was similar for both markers. $\hat{N}_{\mathrm{e}(v)}$ indicates the number of individuals that are effective in the population, i.e., how many of them are able to leave descendants to the following generations. Here, we observed that only approximately $12 \%$ of the individuals that were genotyped for both markers were effective in the population.

The value that was obtained for $S_{(r e f)}$ means that approximately 80 populations of $S$. lycocarpum should be maintained in order to retain an effective size of 500. Taking into account the present scenario of devastation in the Cerrado vegetation and the reduced number of protected areas [only 1-3\% (Ratter et al., 1997; Felfili et al., 2001; Aguiar et al., 2004)], these numbers ought to be considered with caution because the Cerrado remnants might not be ef- 
fectively playing their role in genetic conservation in the long run. The non-protected areas are especially vulnerable to anthropic action and can easily yield monocultures.

Martins (2005) determined that the maximum seed migration distance in S. lycocarpum is about $40 \mathrm{~km}$. In agreement with those results, Moura et al. (2011a,b) observed that populations that are 43 and $45 \mathrm{~km}$ apart showed a significant level of genetic divergence. Therefore, we suggest that at least 80 populations, each separated from the nearest by less than $40 \mathrm{~km}$, should be conserved.

The protected areas in the Cerrado are frequently surrounded by extensive monocultures, within which few, if any, native vegetation remnants can be found. These areas are thus analogous to islands in the middle of an ocean of soybeans or sugarcane, and many of them may become genetically isolated in the short run. Consequently, studies aiming at an effective strategy of genetic conservation need to include contemporary gene flow, minimum viable area, minimum number of populations to be conserved, population size, and maximum among-population distance. The minimum amount of information for the long-run conservation of most species is still unknown, while the agricultural frontier expands into the Cerrado and makes its species more vulnerable to genetic erosion.

\section{REFERENCES}

Aguiar LMS, Machado RB and Marinho-Filho JA (2004). Diversidade Biológica do Cerrado. In Cerrado: Ecologia e Caracterização (Aguiar LMS and Camargo AJA, eds.). EMBRAPA, Cerrados, 17-40.

Courtenay O (1994). Conservation of the maned wolf: fruitful relations in a changing environment. Canid. News 2: 41-43.

Crossa J and Vencovsky R (2011). Basic Sampling Strategies: Theory and Practice. Available at [http://www.mendeley. $\mathrm{com} /$ research/effective-population-size-under-random-mating-with-a-finite-number-of-matings/]. Accessed January 24, 2012.

Felfili JM, Silva Junior MC, Rezende AV, Haridansan M, et al. (2001). O Projeto Biogeografia do Bioma Cerrado: Hipóteses e Padronização da Metodologia. In: Conservação da Biodiversidade em Ecossistemas Tropicais: Avanços Conceituais e Revisão de Metodologias de Avaliação e Monitoramento (Garay I and Dias B, eds.). Editora Vozes, Petrópolis, 157-173.

Martins K (2005). Diversidade Genética e Fluxo Gênico via Pólen e Sementes em Populações de Solanum lycocarpum A. St.-Hil (Solanaceae) no Sudeste de Goiás. 128 f. Tese (Doutorado em Agronomia: Genética e Melhoramento de Plantas). Escola Superior de Agricultura "Luiz de Queiroz" - ESALQ/USP.

Martins K, Chaves LJ, Buso GS and Kageyama PY (2006). Mating system and fine-scale spatial genetic structure of Solanum lycocarpum St.Hil (Solanaceae) in Brazilian Cerrado. Conserv. Genet. 7: 957-969.

Martins K, Chaves LJ, Vencovsky R and Kageyama PY (2011). Genetic structure based on nuclear and chloroplast microsatellite loci of Solanum lycocarpum A. St. Hil. (Solanaceae) in Central Brazil. Genet. Mol. Res. 10: 665-677.

Moura TM, Sebbenn AM, Chaves LJ, Coelho ASG, et al. (2009). Diversidade e estrutura genética espacial em populações fragmentadas de Solanum spp. do Cerrado, estimadas por meio de locos microssatélites. Sci. For. 37: 143-150.

Moura TM, Oliveira GCX and Chaves LJ (2010). Correlação entre floração, frutificação e variáveis ambientais em Solanum lycocarpum A. St.-Hil, Solanaceae. Biosci. J. 26: 457-462.

Moura TM, Sebbenn AM, Martins K, Moreno MA, et al. (2011a). Allelic diversity in populations of Solanum lycocarpum A. St.-Hil (Solanaceae) in a protected area and a disturbed environment. Acta Bot. Bras. 25: 937-940.

Moura TM, Guimarães EFT, Defavari GR, Moreno MA, et al. (2011b). Estrutura genética populacional em Solanum lycocarpum A. St.-Hil (Solanaceae), comparando população natural e sob influencia antrópica, estimados por marcadores isoenzimáticos. Rev. Bras. Biociências 9: 488-491.

Moura TM, Martins K, Sujii PS, Sebbenn AM, et al. (2012). Genetic structure in fragmented populations of Solanum lycocarpum A. St.-Hil. with distinct anthropogenic histories in a Cerrado region of Brazil. Genet. Mol. Res. 11: 2674-2682.

Oliveira-Filho AT and Oliveira LCA (1988). Biologia floral de uma população de Solanum lycocarpum St Hil (Solanaceae) em Lavras, MG. Rev. Bras. Bot. 11: 23-32.

Ratter JA, Ribeiro JF and Bridgewater S (1997). The Brazilian cerrado vegetation and threats to its biodiversity. Ann. Bot. 80: $223-230$. 
Stehmann JR, Mentz LA, Agra MF, Vignoli-Silva M, et al. (2013). Solanaceae in Lista de Espécies da Flora do Brasil. Jardim Botânico do Rio de Janeiro, Rio de Janeiro.Available at [http://floradobrasil.jbrj.gov.br/jabot/floradobrasil/ FB14716]. Accessed November 13, 2013.

Vencovsky R and Crossa J (1999). Variance effective populations size under mixed self and random mating with applications to genetic conservation of species. Crop. Sci. 39: 1289-1294.

Vencovsky R and Crossa J (2003). Measurements of representativeness used in genetic resources conservation of plant breeding. Crop. Sci. 43: 1912-1921. 